Vol 2. No. 1, Januari 2022 P-ISSN : 2774-8030, e-ISSN : 2774-8030

\title{
PERAN DINAS PERHUBUNGAN BAGI KESELAMATAN BERKENDARA MELALUI UJI KIR DAN EDUKASI KEPADA KENDARAAN WAJIB UJI KABUPATEN SEKADAU
}

\author{
DEDE SAPUTRA, ERSA TRI FITRIASARI \\ Dinas Perhubungan Kabupaten Sekadau, Badan Pengembangan Sumberdaya Manusia \\ Provinsi Kalimantan Barat \\ Email : dedesaputra0807@gmail.com, ersa3.dhobithoh@gmail.com
}

\begin{abstract}
ABSTRAK
Dalam memaksimalkan kinerja pemerintahan selaku penyelenggara pelayanan publik menjadi suatu kewajiban bagi pemerintah dalam menyelenggarakan pelayanan publik dengan tingkat kualitas yang terbaik. Bab I Pasal 1 Ayat 1 UU Nomor 25 Tahun 2009, pelayanan publik adalah kegiatan atau rangkaian kegiatan dalam rangka pemenuhan kebutuhan pelayanan sesuai dengan peraturan perundang-undangan. Tingkat kebutuhan masyarakat yang semakin kompleks terhadap pelayanan publik sehingga muncul permasalahan mulai dari faktor keselamatan, faktor keamanan dan kenyamanan. Dinas Perhubungan Kabupaten Sekadau sebagai wujud akuntabilitas publik dengan memberikan pelayanan publik dari fakta dilapangan yaitu tingginya pelanggaran persyaratan teknis dan administrasi kendaraan bermotor wajib uji di Kabupaten Sekadau. Artikel ini bertujuan untuk terlaksana pentingnya Uji KIR dan edukasi bagi keselamatan berkendara. Jenis study penelitian ini adalah deskriptif menggunakan metode survei. Teknik pengumpulan data pada study penelitian deskriptif ini menggunakan teknik observasi dengan menggunakan instrumen penelitian lembar observasi checklist. Hasil study penelitian deskriptif ini digunakan untuk menggambarkan peningkatan pengetahuan dan pemahaman pengguna kendaraan wajib uji setelah menerima uji pengukuran dan edukasi mengenai uji KIR bagi keselamatan berkendara terutama dalam meningkatkan keselamatan dan keamanan berlalu lintas sehingga dapat memberikan keamanan dan keselamatan bagi pengguna jalan lain dan masyarakat sekitar dalam berlalu lintas dan berkendara.
\end{abstract}

Kata kunci: KIR, Aktualisasi dan Edukasi.

\begin{abstract}
In maximizing the performance of the government as a public service provider, it is an obligation for the government to provide public services with the best quality level. Chapter I Article 1 Paragraph 1 of Law Number 25 Year 2009, public services are activities or series of activities in the context of fulfilling service needs in accordance with statutory regulations. The level of community needs that are increasingly complex for public services so that problems arise starting from the safety factor, security factor and comfort. The Sekadau Regency Transportation Office as a form of public accountability by providing public services from the facts on the ground, namely the high violation of technical and administrative requirements for motorized vehicles must be tested in Sekadau Regency. This article aims to implement the importance of the KIR test and education for driving safety. This type of research study is descriptive using a survey method. The data collection technique in this descriptive research study uses observation techniques using a checklist observation sheet research instrument. The results of this descriptive research study are used to describe the increase in knowledge and understanding of mandatory vehicle users after receiving a measurement test and education regarding the KIR test for driving safety, especially in improving traffic safety and security so that it can provide security and safety for other road users and the surrounding community in traffic and driving.
\end{abstract}

Keywords: KIR, Actualization and Education.

\section{PENDAHULUAN}

Tingginya pelanggaran persyaratan teknis dan administrasi kendaraan bermotor wajib 
uji di Kabupaten Sekadau sesuai data yang didapat bahwa jumlah angkutan yang melakukan Uji KIR tahun 2020 di Kabupaten Sekadau yang hanya mencapai 481 jumlah kendaraan yang melakukan uji KIR dari total kendaraan wajib uji sebanyak 3.156 atau hanya mencapai 15,24\%, hal tesebut sangatlah tidak sesuai dengan visiDinas Perhubungan Kabupaten Sekadau yakni Terwujudnya Pelayanan Jasa Transportasi Tertib, Aman dan Lancar,dan Misi Dinas Perhubungan Kabupaten Sekadau yaitu Meningkatkan Disiplin dan Kesadaran Masyarakat dalam ber Lalu Lintas.

Berasal dari bahasa Belanda Keur, KIR adalah proses kegiatan yang dilakukan untuk menguji kelayakan dari kendaraan secara teknis. Apakah nantinya kendaraan layak digunakan di jalan raya atau tidak, semuanya tergantung pada hasil KIR. Pelaksanaan KIR dilakukan setiap enam bulan sekali. Semua kendaraan yang fungsinya untuk mengangkutpenumpang, barang, bahkan keduanya dan plat kuning atau hitam wajibmelakukan KIR. Suatu kendaraan dianggap layak apabila sudah memenuhi persyaratan uji KIR secara teknis dan administrasi. Persyaratan administrasi uji KIR ialah masa berlaku ujikendaraan tersebut selama 6 bulan, yang dibuktikan melalui buku uji. Jika telah melebihi batas waktu yang ditetapkan, kendaraan tersebut wajib memperpanjang masa berlaku melalui pemeriksaan uji berkala. Sedangkan persyaratan teknis nya terdiri dari 27 point.

Dinas Perhubungan Kabupaten Sekadau sebagai wujud akuntabilitas publik dengan memberikan pelayanan publik. Pelayanan pada dasarnya didefinisikan sebagai aktifitas seseorang,sekelompok dan/atau organisasi baik secara langsung maupun tidak langsung untuk memenuhi kebutuhan. Jadi dapat dikatakan bahwa dalam pelayanan terdapat dua aspek yaitu seseorang/organisasi dan pemenuhan kebutuhan. Pasalong, (2010:128). Sebagaimana termuat dalam Undang-Undang Nomor 25 Tahun2009 Tentang Pelayanan Publik, dijelaskan bahwa pelayanan publik adalah kegiatan atau rangkaian kegiatan dalam rangka pemenuhan kebutuhan pelayanan sesuai dengan peraturan perundang-undangan bagi setiap warga negara dan penduduk atas barang, jasa, dan atau pelayanan administratif yang disediakan oleh penyelenggara pelayananpublik.

Undang-Undang yang mengatur soal KIR mobil adalah Nomor 22 Tahun 2009 mengenai Lalu Lintas dan Angkutan Jalan pasal 53 ayat 1. Sedangkan pada ayat 2 tertulis mengenai kegiatan apa saja yang dilakukan saat pengujian. Bahkan apa saja yang diujikan dan menjadi syarat uji kelayakan juga diatur pada pasal 54 dan 55. Masalah uji KIR ini juga tertulis dalam Peraturan Menteri Perhubungan Republik Indonesia Nomor PM 133/ 2015. Isinya mengenai Pengujian berkala kendaraan bermotor serta pengujian wajib dilakukan usai mendapatkan STNK.Selain itu surat hasil uji KIR hanya bisa berlaku enam bulan ke depan yang artinya setahun kendaraan perlu uji KIR dua kali.

Berdasarkan pemaparan latar belakang di atas, makaditemukanlah suatu rumusan masalah yaitu "Bagaimana cara meminimalisir jumlah pelanggaran teknis dan administrasi kendaraan bermotor wajib uji dan tujuan dari penelitian ini adalah meningkatnya jumlah kendaraan wajib uji (mobil penumpang umum, mobil bus, dan mobil barang) yang memenuhi persyaratan teknis dan administrasi serta terlaksana pentingnya Uji KIR bagi keselamatan berkendara terutama dalam meningkatkan keselamatan dan keamanan berlalu lintas dalam kegiatan Uji KIR yaitu pentingnya bagi Keselamatan Berkendara sehingga dapat memberikan keamanan dan keselamatan bagi pengguna jalan lain dan masyarakat sekitar dalam berlalu lintas dan berkendara.

\section{METODE PENELITIAN}

Penelitian ini menggunakan pendekatan penelitian kualitatif, Nazir (2003:54) mengungkapkan bahwa pendekatan kualitatif adalah pendekatan dengan menggunakan data yang berupa kalimat tertulis atau lisan, peristiwa-peristiwa, pengetahuan, atau proyek studi yang bersifat deskriptif pada Dinas Perhubungan Kabupaten Sekadau, Bidang Lalu Lintas dan Angkutan, Seksi Pengujian Sarana Dinas Perhubungan Kabupaten Sekadau. Adapun ruang lingkup penelitian ini dibatasi padaUji KIR bagi keselamatan berkendara melalui media leaflet 
dan penjelasan serta uji test yang dilakukan secara terbuka di kawasan Terminal Lawang Kuari, Steigher dan Pasar Sekadau oleh Seksi Pegujian Sarana. Target jumlah kendaraan yang akan diberikan uji KIR yaitu sebanyak 30 kendaraanwajib uji, baik itu kendaraan mobil penumpang umum, mobil bus, dan mobil barang. Pelaksaanaan kegiatan dengan koordinasi dan pembuatan leaflet mengenai uji KIR bagi keselamatan berkendara, pelaksanaan kegiatan Uji KIR kepada Kendaraan wajib uji dilingkungan Kab. Sekadau (Teminal, Steigher dan pasar lama) serta melakukan evaluasi Uji KIR bagi keselamatan berkendara.

\section{HASIL DAN PEMBAHASAN}

Berasal dari bahasa Belanda Keur, KIR adalah proses kegiatan yang dilakukan untuk menguji kelayakan dari kendaran secara teknis.Apakah nantinya kendaraan layak digunakan di jalan raya atau tidak,semuanya tergantung pada hasil KIR. Pelaksanaan KIR dilakukan setiap enam bulan sekali. Semua kendaraan yang fungsinya untuk mengangkut penumpang, barang, bahkan keduanya dan plat kuning atau hitam wajib melakukan KIR. Undang-Undang yang mengatur soalKIR mobil adalah Nomor 22 Tahun 2009 mengenai Lalu Lintas dan Angkutan Jalan pasal 53 ayat 1 . Sedangkan pada ayat 2 tertulis mengenai kegiatan apa saja yang dilakukan saat pengujian. Bahkan apa saja yang diujikan dan menjadi syarat uji kelayakan juga diatur pada pasal 54 dan 55. Masalah uji KIR ini juga tertulis dalam Peraturanmenteri Perhubungan Republik Indonesia Nomor PM 133/ 2015. Isinya mengenai Pengujian berkala kendaraan bermotor serta pengujian wajib dilakukan usai mendapatkan STNK. Selain itu surat hasil uji KIR hanya bisa berlaku enam bulan ke depan yang artinya setahun kendaraan perlu uji KIR dua kali.

Kendaraan yang tidak melakukan uji KIR ini akan mendapatkan sanksi. Soal sanksi ini juga tertulis dalam Undang-Undang Nomor 22Tahun 2009 mengenai Lalu Lintas dan Angkutan Jalan pasal 76 ayat (1). Ada empat sanksi yang diberlakukan yaitu peringatan tertulis, pembayaran denda, pembekuan izin dan pencabutan izin. Sanksi akan diberikan bertahap mulai dari diperingatkan sampai izin kendaraan dicabut. Sanksi ini akan diberikan pada semua jenis kendaraan tanpa terkecuali, jika terbukti melanggar kegiatan uji KIR. Tingginya pelanggaran persyaratan teknis dan administrasi kendaraan bermotor wajib uji di Kabupaten Sekadau adalah penelitian aktualyang akan di angkat karna menjadi masalah yang dihadapi saat ini. Hal ini sesuai dengan data yang di dapat bahwa jumlah angkutan yangmelakukan Uji KIR tahun 2020 di Kabupaten Sekadau yang hanya mencapai 481 jumlah kendaraan yang uji KIR dari total kendaraan wajib uji sebanyak 3.156 atau hanya mencapai 15,24\%.

Dengan kegiatan penyampaian kepada para penggunakendaraan wajib uji (mobil penumpang umum, mobil bus, dan mobil barang) inilah diharapkan dapat sejalan ditemukan permasalahan yaitu Tingginya pelanggaran persyaratan teknis dan administrasi kendaraan bermotor wajib uji di Kabupaten Sekadau. Sumber dari data kendaraan wajib uji Dinas Perhubungan Kabupaten Sekadau tahun 2020 yakni Capaian layanan Uji KIR Kabupaten Sekadau untuk tahun 2020 yakni 15,24\% atau sebanyak 481 kendaraan dari total keseluruhan kendaraan wajib uji sebanyak 3.156 unit kendaraan baik itu kendaraan Mobil Peumpang Umum, Mobil Bus, Mobil Barang, \& Mobil Gandengan. Kondisi saat sekarang Masih banyaknya kendaraan wajib uji di Kabupaten Sekadau yang tidak melengkapi Persyaratan Teknis dan Administrasi. Diharapkan dengan penelitian ini dapat meningkatkan jumlah kendaraan yang melakukan uji KIR, Sarana uji KIR Dinas Perhubungan Kabupaten Sekadau segera beroperasi dengan kelengkapan operasional Pengujian Kendaraan Bermotor Dinas Perhubungan Kabupaten Sekadau dikarenakan kurangnya Alat Pengujian dengan demikian untuk Kendaraan wajib uji di Lingkungan Kabupaten Sekadau melakukan numpang uji di sarana uji KIR Kabupaten terdekat melalui Surat Rekomendasi Numpang Uji (KIR) dari Dinas Perhubungan Kabupaten Sekadau

Sumber dari data Kompetensi Penguji Kendaraan Bermotor Dinas Perhubungan Kabupaten Sekadau Tahun 2020 yakni Kurangnya tenaga Penguji yang memiliki Kompetensi. Hingga saat ini Unit Pengujian Kendaraan Bermotor Dinas Perhubungan Kabupaten Sekadau 
hanya memiliki 2 Orang Pembantu Penguji, 1 Orang Penguji Pemula, 1 Orang Penguji Tingkat Satu, dan 1 Orang Penguji Tingkat Tiga. Sedangkan untuk jenjang kompetensi Penguji Tingkat dua, Penguji Tingkat Empat, Penguji Tingkat Lima Dan Master Penguji masih belum diisi oleh SDM yang berkompeten.tingkatan kompetensi penguji kendaraan bermotor di Dinas Perhubungan dapat segera terisi dengan penguji yang berkompeten sesuai tingkatannya

Tingginya Pelanggaran Persyaratan Teknis dan Administrasi Kendaraan Bermotor di Lingkungan Kabupaten Sekadau merupakan salah satu masalah utama yang terjadi diDinas Perhubungan Kabupaten Sekadau yaitu rendahnya jumlah Uji KIR Tahun 2020 yang hanya mencapai 481 jumlah kendaraan yang uji KIR dari total kendaraan wajib uji sebanyak 3.156 atau hanya mencapai sebanyak $15,24 \%$. Data tersebut dapat dilihat pada tabel berikut :

Tabel 1. Jumlah Kendaraan Uji KIR Kabupaten Sekadau Tahun 2020

\begin{tabular}{|c|l|c|c|c|}
\hline \multirow{2}{*}{ No } & \multicolumn{2}{|c|}{ Jenis Angkutan } & \multicolumn{3}{|c|}{2020} \\
\cline { 3 - 5 } & & $\begin{array}{c}\text { Jumlah } \\
\text { Kendaraan }\end{array}$ & Jumlah KIR & $\%$ \\
\hline 1 & Mobil Penumpang Umum & 1.085 & - & 0,00 \\
\hline 2 & Mobil Bus & 49 & 5 & 10,10 \\
\hline 3 & Mobil Barang & 1.408 & 465 & 33,03 \\
\hline 4 & Mobil Gandengan & - & - & - \\
\hline \multicolumn{2}{r|}{ JUMLAH } & $\mathbf{3 . 1 5 6}$ & $\mathbf{4 8 1}$ & $\mathbf{1 5 , 2 4}$ \\
\hline
\end{tabular}

(Sumber : Data kendaraan wajib uji tahun 2020)

Berdasarkan tabel diatas, aspek/faktor prioritas dengan ranking tertinggi yaitu "Kurangnya uji KIR dari Dinas PerhubunganKabupaten Sekadau mengenai uji KIR". Aspek prioritas yang dipilih berhubungan dengan penelitian aktual mengenai "Tingginya Pelanggaran Persyaratan Teknis dan Administrasi Kendaraan Bermotor di Lingkungan Kabupaten Sekadau".

Pertimbangan dari aspek penelitian aktual ini adalah untuk meningkatkan pengetahuan dan pemahaman para pengguna kendaraan wajib uji yaitu Mobil Penumpang Umum, Mobil Bus dan Mobil Barang mengenai uji KIR yang sesuai dalam Undang-Undang Nomor 22 Tahun 2009 tentang Lalu Lintas dan Angkutan Jalan yang diatur pada Pasal 53 Ayat 1 tentang KIR, Masalah uji KIR ini juga tertulis dalam Peraturan menteri Perhubungan Republik Indonesia Nomor PM 133/ 2015. Isinya mengenai Pengujian berkala kendaraanbermotor serta pengujian wajib dilakukan usai mendapatkan STNK. Melalui uji KIR dari Dinas Perhubungan Kabupaten Sekadau dalam rangka menghasilkan nilai bermanfaat untuk masyarakat pengguna kendaraan dan menghasilkan dampak positif yaitu:

a. Dapat meminimalkan kecemasan dan rasa tidak aman bagi pengguna jalan lain dan masyarakat sekitar dalam berlalu lintas danberkendara

b. Terjadinya peningkatan jumlah kendaraan yang akan melakukan Uji KIR

c. Memberikan edukasi uji KIR bagi keselamatan berkendara melalui paparan, uji test dan media leaflet kepada kendaraan wajib uji di lingkungan Kabupaten Sekadau.

Demi meningkatkan Keselamatan dan Keamanan Berlalu Lintas, Dinas Perhubungan Kabupaten Sekadau wajib melakukan kegiatan rutin pelaksanaan uji KIR mengenai uji KIR bagi keselamatan berkendara wajib uji di lingkungan Kabupaten Sekadau. Uji KIR dan edukasi dapat menambahwawasan dan pengetahuan kepada pengendara kendaraan dan masyarakat akan pentingnya melakukan uji KIR demi keselamatan berkendara. Pelaksanaan kegiatan Uji KIR kepada Kendaraan wajib uji di lingkungan Kab. Sekadau (Teminal, Steigher dan pasar lama)

Berdasarkan hasil evaluasi pretest dan post test, dapat disimpulkan bahwa kegiatan uji 
KIR mengenai uji KIR bagi keselamatan berkendara efektif untuk meningkatkan pemahaman dan pengetahuan para pengguna kendaraan wajib uji. Hal ini ditunjukkan dari adanya perbedaan yang signifikan pada nilai pengguna kendaraan sebelum dan sesudah mendapatkan uji KIR terkait uji KIR. Pada saat pelaksanaan pretest, skor rata-rata yang diperoleh adalah 44.Namun pada saat pelaksanaan post test setelah menerima uji KIR, terjadi peningkatan hingga mencapai rata-rata skor 90 . Hal tersebut sangat memberikan gambaran positif akan meningkatnya kendaraan wajib uji yang akan melakukan uji KIR kedepannya.

Pelaksanaan kegiatan uji KIR mengenai uji KIR bagi keselamatan berkendara yang dilaksanakan bertempat di Terminal Lawang Kuari, Steigher dan Pasar Lama Kabupaten Sekadau. Melalui pretest dan post test kepada 30 pengguna kendaraan wajib uji yaitu mobil penumpang umum, mobil, bus dan mobil barang. Dengan jumlah soal yang tedapat dalam pretest dan post test masing-masing 5 soal yang sama. Kegiatan ini dilakukan pada hari kerja di jam 07.30 - 10.30 dan jam 14.00 - 16.00.

Berdasarkan kegiatan tersebut petugas melakukan penilaian dari hasil jawaban yang didapat sebagai berikut :

\begin{tabular}{|c|c|c|}
\hline NILAI & PRE TEST & POST TEST \\
\hline 20 & 5 Jawaban & 0 Jawaban \\
\hline 40 & 14 Jawaban & 0 Jawaban \\
\hline 60 & 11 Jawaban & 0 Jawaban \\
\hline 80 & 0 Jawaban & 15 Jawaban \\
\hline 100 & 0 Jawaban & 15 Jawaban \\
\hline Jumlah & 1320 & 2700 \\
\hline Nilai Rata-rata & 44 & 90 \\
\hline
\end{tabular}

Sesuai data penilaian yang telah dihitung di atas, maka terdapat peningkatan pengetahuan dan pemahaman pengguna kendaraan wajib uji setelah menerima uji KIR mengenai uji KIR dan terlaksananya pentingnya Uji KIR bagi keselamatan berkendara terutama dalam meningkatkan keselamatan dan keamanan berlalu lintas sehingga dapat memberikan keamanan dan keselamatan bagi pengguna jalan lain dan masyarakat sekitar dalam berlalu lintas dan berkendara.
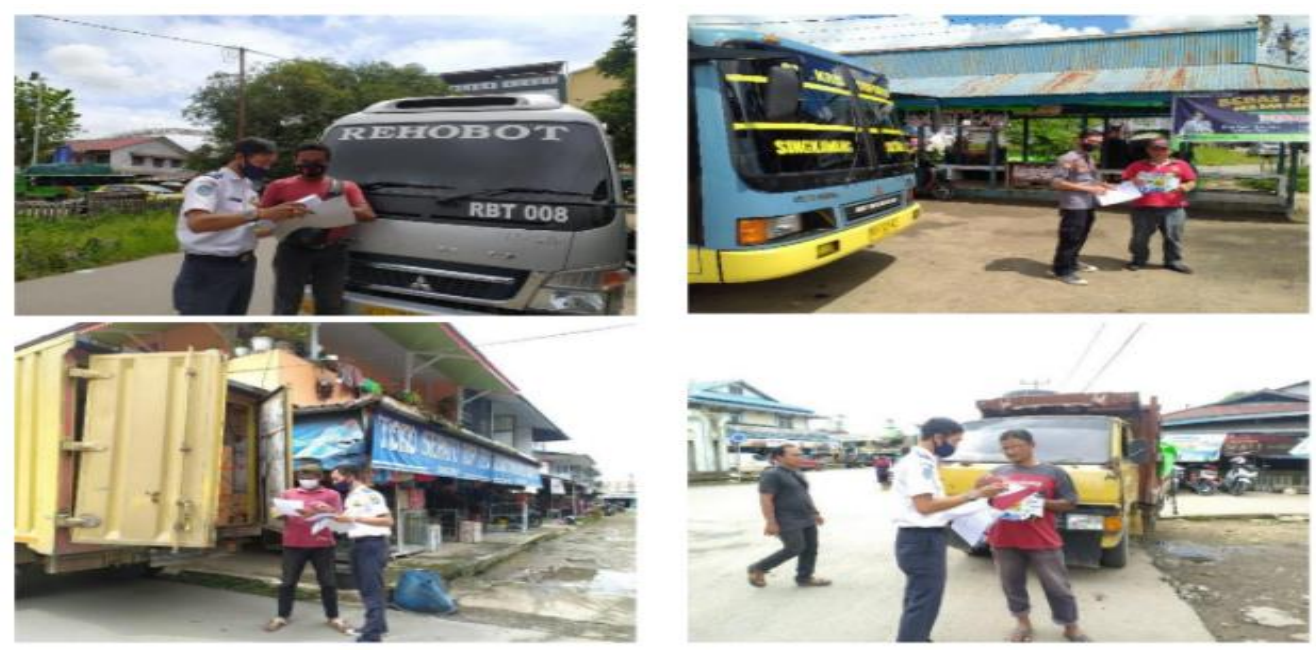

Gambar 1. Edukasi kepada Pengendara Kendaraan Bermotor

Dinas Perhubungan mengenai peningkatan pemahaman dan pengetahuan masyarakat 
khusunyapengguna kendaraan wajib uji akan pentingnya melakukan uji KIR bagikeselamatan berkendara. Selain itu kegiatan ini juga bisa menjadi contoh untuk melaksanakan kegiatan mengenai rutinitas uji KIR uji KIR yang akan dilakukan kedepannya.

\section{KESIMPULAN}

Pelaksanaan Penelitian ini dilaksanakan agar terjadi peningkatan terhadap jumlah kendaraan wajib uji (mobil penumpang umum, mobil bus, dan mobil barang) yang memenuhi persyaratan teknis dan administrasi sehingga mengurangi tingkat kecelakaan dalam berkendaraan. Terlaksananya peran Dinas Perhubungan dan edukasi kepada masyarakat tentang Uji KIR bagi keselamatan berkendara sebagi wujud edukasi kepada masyarakat dan pengguna kendaraan.

Dilakukan rutinitas kegiatan uji KIR guna meningkatkan pemahaman dan pengetahuan masyarakat akan uji KIR yang akan berpengaruh pada penurunan jumlahpelanggaran persyaratan teknis dan administrasi kendaraan bermotor wajib uji di Kabupaten Sekadau. Dapat terealisasi untuk operasional Pengujian Kendaraan Bermotor Dinas Perhubungan Kabupaten Sekadau dengan tidak melakukan numpang uji di sarana uji KIR Kabupaten terdekat Pemenuhan SDM yang berkompeten.tingkatan kompetensi penguji kendaraan bermotor di Dinas Perhubungan dapat segera terisi dengan penguji yang berkompeten sesuai tingkatannya

\section{DAFTAR PUSTAKA}

Denhardt, Kathryn G. 1988. The ethics of Public Service. Westport, Connecticut : Greenwood Press.

Nazir, Moh. 2003. Metode Penelitian. Jakarta : Ghalia Indonesia

Pasolong, Harbani. 2010. Teori Administrasi Publik, Alfabeta, Bandung.

Peraturan Menteri Perhubungan Republik Indonesia Nomor PM 133/ 2015,Pengujian Berkala Kendaraan Bermotor, Jakarta

Rasul,Syahrudin, 2003. Pengintegrasian Sistem Akuntabilitas Kinerja danAnggaran dalam Perspektif UU No.17/2003 Tentang Keuangan Jegara.Jakarta:PNRI.

Turner,Mark and Hulme,David,1997.Governance. Administrasi, and Development:Making The State Work. London: MacMillan PressLtd.

Undang-Undang Nomor 22, 2009. Lalu Lintas dan Angkutan Jalan, JakartaUndang-Undang Nomor 25 Tahun 2009 tentang Pelayanan Publik

Undang-Undang Nomor 25 Tahun2009 Tentang Pelayanan Publik 